\title{
Private school reform through learning community: Evidence from Muhammadiyah School
}

\author{
L.A. Perguna*, H. Sutanto \& J.H.G. Purwasih \\ Universitas Negeri Malang, Malang City, Indonesia
}

\begin{abstract}
Private schools are facing a dilemma. Schools must continue to look for students to maintain their income as well as improving education's quality, both of which required hard work. This article focuses on how private schools improve the quality of their learning through teacher learning communities on Lesson Study through the SWOT analysis. A qualitative method was used to explore schools' reformation through teachers' learning communities within junior high private schools. The results showed that the Lesson Study provided positive changes for both teachers and school development following the relationship building of trust and openness principle. Learning communities that have been formed with the Lesson Study principles provided changes not only in the learning-based process but also in schools' development. The reformation of private class to the public sphere affects schools' reformation.
\end{abstract}

Keywords: Reform, Lesson Study, Learning Community, Private School, Public Philosophy

\section{INTRODUCTION}

The 4.0 industrial revolution continuously echoed coinciding with the pandemic presence that has changed the entire structure of society, from bureaucracy to civil society and the education sector. Education must be ready to face the upcoming changes, including changes in learning patterns from traditional old learning systems to digital and virtual learning. All education stakeholders must act and be prepared in facing these changes. Simultaneously, education must also be vigilant to repress the negative impact of science and technology development (Stepanek 2001). At the forefront of education, schools and all their elements must be adaptive and adoptive in facing challenges in this disruptive era. The students are digital natives, which is different from the teachers who are digital immigrants. Thus, the demands to change are enormous following the bigger challenge to face (Germain-Mc Carthy 2013).

Looking through the history of Indonesia, the public and the private sector's role in education cannot be underestimated. Historically, private education had been a driving key element of education in the country. The Islamic boarding school, which is mostly managed by the Nahdlatul Ulama social organization, and schools managed by the Muhammadiyah organizations long before Indonesia independence are examples. Now, with the presence of the 4.0 industrial revolution and the pandemic, the real challenge of digitization is materialized within the learning system. This big challenge demands bigger changes, especially for private schools. Many private schools are developing and growing, but the number of private schools that started to collapse also escalates.

There are various ways for schools to improve, one of which is through Lesson Study (LS) which has been recognized by teachers and educators in many countries. LS is a professional teacher development effort to improve teaching and student learning through practice-oriented, student learning- focused, collaborative and observation-based research which is conducted by the

\footnotetext{
*Corresponding author: luhung.fis@um.ac.id
} 
teacher or the learning community (Bell \& Gilbert 2004; Fernandez 2002; Fernandez \& Yoshida 2004; Murata \& Takahashi 2002; Wang-Iverson \& Yoshida 2005). Regardless of the high number of researchers and schools using the LS as a professional development approach, LS remains relatively new in Indonesia with various additional issues, especially in private schools located on the outskirts of Surakarta city. LS's functions in the teaching learning process in schools, including its contributions to school development, are discussed in this article.

\section{METHOD}

The research used a qualitative descriptive approach with various data collection techniques. To collect data, researchers interacted with informants or participants and reported the observation results. Researchers conducted participatory observations on learning communities based on LS, involving teachers at school, and carried out LS learning activities from the planning stage, open lesson and reflection. The study documentation was carried out by collecting school curriculum data and school development blueprints. Focus group discussions were carried out with the related informants, while the data analysis was completed using informants' answers based on the research focus. The research location was SMP (Junior High) Muhammadiyah 2 Surakarta, Indonesia. The data were obtained purposively from the school's person in charge of the LSLC, the school's committee, teachers, students and students' parents. The data analysis was conducted by triangulation to see how LSLC impacted schools.

\section{RESULT AND DISCUSSIONS}

\subsection{SWOT in lesson study based learning community}

In the midst of high demands, private schools must be creative and innovative in developing and pursuing schools to grow more advanced. Once they are not creative and innovative, they may lose social capital and students, which results in schools' closing. In Surakarta, at least four private schools have been shut down. Failure in acquiring students becomes one of the main reasons. Besides, the collapse is also caused by many closely related factors such as lack of facilities and infrastructure, human resources factors including an institution's limited creativity and discrimination between private and public schools by the community and even the government. This became a record and reflection for the other private schools in Surakarta, including Muhammadiyah schools as part of private schools. There are 42 Muhammadiyah schools in Surakarta, ranging from elementary to senior high schools. At the junior high school level, there are 8 SMP and 1 Madrasah Tsanawiyah. All schools had experienced a fluctuating development with a different number of students. Thus, schools are required to make breakthroughs within their development.

One of the breakthroughs that have been implemented is building Learning Community (LC) with LS principles and characteristics. In March 2018, a Learning Community was formed at the school. There are two goals set for its establishment. The first goal is to facilitate teachers to learn and discuss professional development in learning. This LC also involves the school's principal not as a leader but as a member of the LC. The principle of "monologue," which the principal often used, was changed to the principle of "dialogue." After intensive discussion, LC implements ways of making the previously private class, owned by teachers with the subject being taught, becoming public property following LS's characteristics. This school's publicly owned class is the first public class of Muhammadiyah School in Surakarta. The public class allows anyone to attend and participate in the learning process. Students' parents are allowed to observe the students learning in class. This is a means of promoting the school to the public.

Several stages of LS, starting from lesson design, the open lesson to reflection, are carried out through the learning community. The preparation of lesson design is not solely conducted by the class teachers but together with the other teachers who have free time. They have a discussion 
Table 1. SWOT in establishing LS-based schools

\begin{tabular}{|c|c|}
\hline Strength & Weakness \\
\hline $\begin{array}{l}\text { Homogeneous Teacher-Student. } \\
\text { The majority of the teachers are digital natives } \\
\text { who have a high desire to learn and change. } \\
\text { The principal is very supportive of school } \\
\text { development policies, including the LS program. } \\
\text { The lesson design is on only } 1 \text { page, which made } \\
\text { teachers interested. } \\
\text { Teachers get a lot of input from peer-to-peer } \\
\text { records in LS. }\end{array}$ & $\begin{array}{l}\text { Student input are the remnant from public schools. } \\
\text { Students' families with a lower-middle economy } \\
\text { focus on their respective Obs. } \\
\text { Teachers are busy with administrative affairs. } \\
\text { It takes time to change student and teacher behavior } \\
\text { from individual to inquiry-based } \\
\text { collaborative learning. }\end{array}$ \\
\hline Opportunities & Threat \\
\hline $\begin{array}{l}\text { The Muhammadiyah Foundation fully supports } \\
\text { school activities } \\
\text { Schools are free to determined school } \\
\text { development policies }\end{array}$ & $\begin{array}{l}\text { Support from the government is different from } \\
\text { that of the public schools. } \\
\text { Stigma against private schools rather than } \\
\text { public schools both economically and academically } \\
\text { LSLC is yet to be a national policy }\end{array}$ \\
\hline
\end{tabular}

to find the best strategies and models for learning based on the observations they have done before. The principle of no students should be left behind in learning is primarily used in the process of preparing lesson design. The dialogue principle, collaborative and active education is also emphasized in its formulation. This design is made on only one sheet of paper with the main components of introduction - core activities - closing activities along with its objectives and learning indicators (Purwasih \& Perguna 2018)

As the time is determined, the next step is Open Lesson. The teachers who carry out this activity are invited LC members, teachers from other schools, and students' parents in that class. Classes that are often held exclusively for students and teachers now become open. This openness is a symbol that teaching is not a monologue and didactic and is also a symbol of building trust with the public. Simultaneously, support from all parties is needed to achieve the desired quality in learning activities. Classroom learning that emphasizes inquiry activities, a two-way dialogue of students' ideas, and meaningful content exploration facilitated by the teacher is a very challenging endeavor. Invited teachers and guests observe the class focusing on student learning rather than how the teacher teaches.

After the open class, reflection is carried out to see whether students can focus on learning, whether they have difficulties in focussing and the reasons behind that. Some of these questions came up in the reflection stage. The reflection results contain several alternative solutions in learning to be followed up in the next open class with a different teacher. These three processes are new methods and have deconstructed the teacher's behavior in their comfort zone. This emphasis on student learning in the LS process reminds the teachers of the importance of understanding students' ideas and helps them to bring a reformation vision within their classrooms. Classroom reformation from private to public (micro-level) will impact schools' reformation (macro-level). In one year, the school had carried out the class reform activities for 4 LS cycles. This figure is considered high for schools that have just practiced the LS.

Researchers as observers in LS activities in school use Mead's term of the Looking Glass Self by using the SWOT analysis (Strength, Opportunities, Weakness, Threat), especially in a micro-scale that occurred in schools, as presented in Table 1.

LS-based learning facilitates value changes that have been deeply rooted in learning. Teachers are preoccupied with many school's administrative matters and rarely have the opportunity to see other teachers or even discuss their teaching. The teachers focus more on students getting good grades 
or being different from others. In teaching, the teacher relies on familiar, repeated routines and roles in the classroom, such as giving homework, giving assignments in class, delivering material and new skills, and asking students to practice them (McLaughlin \& Talbert 2006). This was done for teachers as teaching is a personal activity. There are values and norms (cultural conservatism) that inhibit and oppose traditional teacher norms from learning from one another (Collinson \& Cook 2006; Hiebert \& Stigler 2017). The norms barrier is both cultural and structural. This LS community-based learning is gradually reforming the individualist, conservatism classroom to dialogic and collaborative inquiry-based learning (McLaughlin \& Talbert 2006; Vescio et al. 2008). Teachers' communities are more likely to innovate efficiently, as teachers need knowledge and various pedagogical strategies for learning. This community mediates those necessities due to collegial interactions that occur through meetings and observations.

\section{CONCLUSION}

In the community, as homo socius, teachers interact on developing and re-developing their skills, knowledge, beliefs and philosophy of teaching and learning. The concept of learn-unlearn-relearn is carried out by teachers in the community. This study explains how Lesson Study-based learning communities, with their advantages and disadvantages, have succeeded in reforming teachers' learning. Through the community, teachers learn that teaching is an active dialogue and collaborative effort to plan the lesson designs that lead to students' success in education. This paradigm shift takes a reasonably long period of at least one year. This study provides evidence that individualism and conservatism can shift toward collectivity as long as there is goodwill from schools' principals and the foundations. The teacher and classroom reformation carries a multiplier effect for schools in becoming more open and democratic.

\section{REFERENCES}

Bell, B. and Gilbert, J. (2004) 'A model for achieving teacher development', The Routledge Falmer reader in science education, pp. 258-278.

Collinson, V. and Cook, T. F. (2006) Organizational learning: Improving learning, teaching, and leading in school systems. Sage.

Fernandez, C. (2002) 'Learning from Japanese approaches to professional development: The case of Lesson Study', Journal of Teacher Education. doi: 10.1177/002248702237394.

Fernandez, C. and Yoshida, M. (2004) 'Lesson Study: A case of a Japanese approach to improving instruction through school-based teacher development'. Mahwah, NJ: Lawrence Erlbaum.

Germain-Mc Carthy, Y. (2013) Bringing the NCTM standards to life: Exemplary practices for middle school. Routledge.

Hiebert, J. and Stigler, J. W. (2017) ‘Teaching Versus Teachers as a Lever for Change: Comparing a Japanese and a U.S. Perspective on Improving Instruction', Educational Researcher. doi: 10.3102/0013189X17711899.

McLaughlin, M. W. and Talbert, J. E. (2006) Building school-based teacher learning communities: Professional strategies to improve student achievement. Teachers College Press.

Murata, A. and Takahashi, A. (2002) 'Vehicle To Connect Theory, Research, and Practice: How Teacher Thinking Changes in District-Level Lesson Study in Japan.'

Purwasih, J. H. G. and Perguna, L. A. (2018) 'MENGENALKAN LESSON STUDY MELALUI PELATIHAN GURU DI LINGKUNGAN MADRASAH ALIYAH KABUPATEN MALANG', Jurnal Praksis dan Dedikasi Sosial. doi: 10.17977/um032v0i0p80-86.

Stepanek, J. (2001) 'A New View of Professional Development.', Northwest teacher, 2(2), p. 2.

Vescio, V., Ross, D. and Adams, A. (2008) 'A review of research on the impact of professional learning communities on teaching practice and student learning', Teaching and Teacher Education. doi: 10.1016/j.tate.2007.01.004.

Wang-Iverson, P. and Yoshida, M. (2005) Building our understanding of Lesson Study. Research for Better Schools. 